\title{
Selection of lactic acid bacteria producing bacteriocin
}

\author{
Tuyển chọn vi khuẩn lactic có khả năng sinh bacteriocin \\ Research article
}

Ha, Thi Quyen ${ }^{1 *}$; Hoa, Thi Minh Tu ${ }^{2}$

${ }^{I}$ VNU University of Engineering and Technology, 144 Xuan Thuy Road, Cau Giay, Hanoi, Vietnam; ${ }^{2}$ Institute of Biotechnology, Vietnam Academy of Science and Technology, 18 Hoang Quoc Viet, Hanoi, Vietnam

\begin{abstract}
Lactic acid bacteria were isolated from 10 samples of the traditionally fermented foods ( 5 samples of Vietnamese fermented pork roll and 5 samples of the salted field cabbage) and 5 samples of fresh cow milks collected from households in Vietnam. 22 strains of lactic acid bacteria were isolated for inhibition to Lactobacillus plantarum JCM 1149. Of these, only 2 strains including DC1.8 and $\mathrm{NC} 1.2$ have rod shape, the others have coccus shape. 7 strains showing higher antibacterial activity were selected for checking spectrum of antibacteria with indicator bacteria consistting of Bacillus subtilis ATCC 6633, Enterococcus faecium JCM 5804 and Staphylococcus aureus TLU. By which, 3 strains including NC3.5 (from Vietnamese fermented pork roll), DC1.8 (from salted field cabbage) and MC3.19 (from fresh cow milk) were selected because of their higher antibacterial ability. However, the antibacterial activity of the lactic acid bacteria can be based on their disposable compounds and some other antibacterial compounds produced during their growth (such as lactic acid, $\mathrm{H}_{2} \mathrm{O}_{2}$, bacteriocins, etc.). For seeking lactic acid bacteria with capability of producing bacteriocins, antibacterial compounds with protein nature, 3 above strains were checked sensitiveness to proteases (including protease $\mathrm{K}$, papain, $\alpha$ - chymotrypsin and trypsin). Because bacteriocins are proteinaceous antibacterial compounds, so their antibacterial activity will be reduced if proteases are added. The result showed DC1.8 and MC3.19 were capable of producing bacteriocin during culture process. They were identified as Lactobacillus acidophilus and Lactococcus lactis and classified, respectively, based on analysis chemical characterisitcs by standard API 50 CHL kit and phylogeny relationship by $16 \mathrm{~s}$ rRNA sequences.
\end{abstract}

Các chủng vi khuẩn lactic đự̛c phân lập tù̀ 10 mẫu thực phẩm lên men truyền thống (5 mẫu nem chua, 5 mẫu dua cải be muối) và 5 mẫu sữ bò tuơ được thu thập tù các hộ gia đình ở Việt Nam. 22 chủng vi khuẩn lactic đã được phân lập với tiêu chí có khả năng kháng lại vi khuẩn kiểm định Lactobacillus plantarum JCM 1149. Trong số đó, 2 chủng DC1.8 và NC1.2 có tế bào hình que, các chủng còn lại có tế bào hình cầu. 7 chủng thể hiện hoạt tính kháng khuẩn cao được lưa chọn để xác định phổ kháng khuẩn rộng hơn với ba loài vi khuẩn kiểm định Bacillus subtilis ATCC 6633, Enterococcus faecium JCM 5804 và Staphylococcus aureus TLU. Tù đó lưa chon đurợc 3 chủng có hoạt tính kháng khuẩn cao hơn hẳn. Các chủng này gồm NC3.5 phân lập tù̀ nem chua, DC1.8 phân lập tù̀ dưa cải be muối và MC3.19 phân lạp tù sữa bò tuooi. Tuy nhiên, hoạt tính kháng khuẩn của vi khuẩn lactic bao gồm nhũng hợp chất nội tại có trong nó và cả nhũng hợp chất được sinh ra trong quá trình phát triển của nó (nhu axit lactic, $\mathrm{H}_{2} \mathrm{O}_{2}$, bacteriocin, ...). Với định huoóng tìm chủng vi khuẩn lactic có khả năng sinh bacteriocin, chất kháng khuẩn có bản chất protein, 3 chủng trên được kiểm tra độ nhạy cảm với các protease (gồm protease K, papain, $\alpha$-chymotrypsin và trypsin). Do bacteriocin là chất kháng khuẩn có bản chất protein nên hoạt tính kháng khuẩn của chúng sẽ bị giảm nếu protease được bổ xung vào. Kết quả lự chọn được chủng DC1.8 và MC3.19 có khả năng sinh bacteriocin. Hai chủng này đuợc phân loại đến loài nhò̀ vào phân tích đặc điểm sinh hóa bằng kit API 50 CHL và mối quan hệ di truyền thông qua trình tụ gen 16s rRNA. Kết quả phân loại đã xác định chủng DC1.8 thuộc loài Lactobacillus acidophilus và chủng MC3.19 thuộc loài Lactococcus lactis.

Keywords: lactic acid bacteria, antibacterial activity, bacteriocins, Lactobacillus acidophilus, Lactococcus lactis, 16s rRNA 


\section{Introduction}

Food poisoning usually occurs simultaneously in many people due to eating foods that contain bacteria secreting toxins. Currently, the food preservation by using chemicals are restricted due to unwanted effects. Thus, people have been seeking natural compounds with capable of inhibiting microorganisms that cause food poisoning. These compounds can be lactic acid, $\mathrm{H}_{2} \mathrm{O}_{2}$, bacteriocin, etc.

Lactic acid bacteria are traditionally used as starter cultures involved in the fermentation of foods and beverages, because they contribute to flavour and aroma development and to spoilage retardation (Gilliland S.E., 1986). The preservative efficiency is mainly due to acidic conditions that these bacteria create in food during their development, but they are capable of producing antimicrobial compounds, including bacteriocins (De Vuyst L., Vandamme E.J., 1994).

Bacteriocins are proteinaceous antibacterial compounds that inhibit the development of Gram-positive bacteria and closely related species (De Vuyst L., Vandamme E.J.,1994). That is why bacteriocins of lactic acid bacteria are of particular interest as natural preservatives in foods safely and effectively (Stiles M.E.,1996). In Vietnam, the generation of lactic acid bacteria appear mainly in the traditional fermented foods, a resource for providing lactic acid bacteria abundantly.

This study was carried out with the aim of selection lactic acid bacteria that are capable of producing antibacterial compounds as bacteriocin from fermented foods and fresh milk of Vietnam to apply for food preservation.

\section{Materials and methods}

\subsection{Materials}

Sample sources: Five samples of Vietnamese fermented pork roll and five samples of salted field cabbage were collected from the households in Ve village, Hanoi, Vietnam, named NH1 to NH5 and DH1 to DH5, respectively. Five samples of fresh cow milks were from the households in Ba Vi, Hanoi, designated MH1 to MH5.

Indicator bacreria: Lactobacillus plantarum JCM1149, Bacillus subtilis ATCC 6633, Enterococcus faecium JCM 5804 and Staphylococcus aureus TLU were received from Institute of Biotechnology, Vietnam Academy of Science and Technology.

Bacteria culture media: MRS, MRS agar (De Man, Rogosa and Sharpe).

\subsection{Methods}

Isolation of lactic acid bacteria: $1 \mathrm{~g}$ of each sample were homogenized in $9 \mathrm{ml}$ sterilized saline, diluting the samples to reach the concentration of $10^{-1} \div 10^{-8}$. To distinguish the acid-producing bacteria from other bacteria, $1 \% \mathrm{CaCO}_{3}$ was added to the MRS agar. $50 \mathrm{ml}$ of each concentration was spread directly onto the surface of MRS agar plates containing $1 \% \mathrm{CaCO}_{3}$. Incubation of these plates at $30^{\circ} \mathrm{C}$ within 24-36 hours. Colonies of lactic acid bacteria were identified by a clear zone around each colony, and were randomly selected from MRS plates and purified by replacing on MRS agar plates. Colonies were reselected and initially examined for Gram staining and production of catalase. Only Gram-positive, catalase-negative strains were selected.

\section{Detection of antibacterial activity:}

Method 1: The isolates were cultured in MRS media overnight. Using sterile toothpicks to move cultured solution onto MRS agar plates. The MRS plates were incubated for 24 hours at $30^{\circ} \mathrm{C}$. After incubation, a layer of $15 \mathrm{ml}$ of MRS media containing $0,7 \%$ agar and $0,5 \%$ indicator strain of $L$. plantarum JCM1149 was coated on surface of the above MRS plates, kept at $4^{\circ} \mathrm{C}$ for $4 \div 6$ hours, continued incubation at $37^{\circ} \mathrm{C}$ for 24 hours. Antibacterial activity of the lactic acid bacteria was determined based on inhibition zones around each colony (zones of no bacteria, $\mathrm{mm}$ ) (Schillinger et al., 1989).

Method 2: The isolates were cultured in MRS at $30^{\circ} \mathrm{C}$ in 14 $\div 16$ hours, centrifuged to obtain cell free supernatant. The indicator strains were incubated in MRS media at $37^{\circ} \mathrm{C}$ overnight. $0,5 \%$ of the each indicator strain was added in MRS containing 0,7\% agar, mixed well and poured into different plates. Creatting round wells on the plates with $10 \mathrm{~mm}$ in diameter $(\mathrm{d}, \mathrm{mm}) .100 \mu \mathrm{l}$ of the each cell free supernatant were dropped in the wells. Keepping at $4{ }^{\circ} \mathrm{C}$ for 4 hours and then incubating at $37^{\circ} \mathrm{C}$ for 20 hours. Mesuring of inhibition zones through $d(D$, $\mathrm{mm})$. Antibacterial activity was calculated by D-d ( $\mathrm{mm})$.

Sensitive capability with proteases: Determination antibacterial activity of the isolates by bacteriocin or other compounds, protease $\mathrm{K}$, papain, $\alpha$ - chymotrypsin and trypsin were added to the cell free supernatants. Detection of antibacterial activity of the cell free supernatent was carried out by method 2. Positive control: the cell free supernatant was not added protease. L. plantarum JCM1149 was used as indicator strain in this experiment.

Classification of lactic acid bacteria: Shape and physiological analysis was carried out as described by Teuber $\mathrm{M}$. (2003). Standard API 50 CHL kit was used for assessment of sugars fermentation according to the procedures described by the manufacturer.

Genetic tests: Sequence analysis of $16 \mathrm{~S}$ rDNA were used to classify and identify the lactic acid bacterial isolates. PCR was carried out by using primers:

\section{SF: 5'-AGAGTTTGATCCTGGCTCAG-3' 16SR: 5'-TACGGTTACCTT GTTACGACTT-3'}

The components of PCR: Buffer for Taq polymerase 10x: $5 \mu \mathrm{l}$; dNTPs $10 \mathrm{mM}$ : $2 \mu \mathrm{l}$; Dream Taq polymerase 5000U/ml: 0,3 $\mu \mathrm{l}$; Primer 16SF 10pmol: $1 \mu \mathrm{l}$; Primer 16SR 10pmol: $1 \mu 1$; ADN template 20ng: $2 \mu 1$; DI water: $38,7 \mu 1$. 
The process of PCR: set up at $95^{\circ} \mathrm{C}$ in 3 minutes.; $95^{\circ} \mathrm{C}$ in 1 minute; $55^{\circ} \mathrm{C}$ in 1 minute; $68^{\circ} \mathrm{C}$ in 1 minute 15 seconds; $70^{\circ} \mathrm{C}$ in 7 minutes; keeping at $4{ }^{\circ} \mathrm{C}$; repeatting 30 cycles. PCR products were checked by agarose gel electrophoresis and purified by Kit GeneJET ${ }^{\mathrm{TM}}$ Gel Extraction (Fermentas, Canada). PCR products were sequenced by ABI-377 Perkin Elmer machine.

Software MEGA3 was used to determine phylogenetic relationships of strains.

\section{Results and discussions}

\subsection{Isolation and detection of antibacterial activity of lactic acid bacteria}

Lactic acid bacteria were selected based on characteristics as follows: coccus or rod-shaped, gram-positive, catalasenegative, resolving $\mathrm{CaCO}_{3}$ and having antibacterial activity to Lactobacillus plantarum JCM1149.

A total of 22 acid-producing bacteria were isolated from the samples (Table 1). Of these, 7 strains were isolated from Vietnamese fermented pork roll, 9 strains were isolated from salted field cabbage, others were isolated from fresh cow milk. All of 22 strains were capable of resistance to the development of L. plantarum JCM1149. There are 7 strains with high antibacterial activity (diameter of no bacteria zone $>10 \mathrm{~mm}$ ), including NC1.2, NC3.5, DC1.8, DC2.10, DC4.13, MC2.18, MC3.19. These strains were mainly isolated from NH1, NH3, DH1, DH2, DH4, MH2 and $\mathrm{MH} 3$. Of the above 7 strains, only NC1.2 and DC1.8 were rod shape, the others were coccus shape.

Table1. Shape characteristics and antibacterial activity of the isolates

\begin{tabular}{|c|c|c|c|}
\hline Strain number & Sample source & Shape & Antibacterial activity for L. plantarum JCM1149 \\
\hline NC1.1 & NH1 & $\mathrm{C}$ & $+{ }^{1}$ \\
\hline $\mathrm{NC} 1.2$ & NH1 & $\mathrm{R}$ & +++ \\
\hline NC2.3 & $\mathrm{NH} 2$ & $\mathrm{C}$ & ++ \\
\hline $\mathrm{NC} 3.4$ & NH3 & $\mathrm{R}$ & ++ \\
\hline NC3.5 & NH3 & $\mathrm{C}$ & +++ \\
\hline NC4.6 & NH4 & $\mathrm{C}$ & + \\
\hline NC5.7 & NH5 & $\mathrm{C}$ & ++ \\
\hline DC1.8 & DH1 & $\mathrm{R}$ & +++ \\
\hline DC1.9 & DH1 & $\mathrm{C}$ & + \\
\hline DC2.10 & DH2 & $\mathrm{C}$ & +++ \\
\hline DC3.11 & DH3 & $\mathrm{R}$ & + \\
\hline DC4.12 & DH4 & $\mathrm{C}$ & + \\
\hline DC4.13 & DH4 & $\mathrm{C}$ & +++ \\
\hline DC4.14 & DH4 & $\mathrm{R}$ & ++ \\
\hline DC5.15 & DH5 & $\mathrm{C}$ & ++ \\
\hline DC5.16 & DH5 & $\mathrm{C}$ & + \\
\hline MC1.17 & MH1 & $\mathrm{C}$ & ++ \\
\hline MC2.18 & MH2 & $\mathrm{C}$ & +++ \\
\hline MC3.19 & МH3 & $\mathrm{C}$ & +++ \\
\hline MC3.20 & MH3 & $\mathrm{C}$ & ++ \\
\hline MC4.21 & MH4 & $\mathrm{C}$ & ++ \\
\hline MC5.22 & MH5 & $\mathrm{C}$ & + \\
\hline
\end{tabular}

The 7 above strains were selected to check for inhibition to Bacillus subtilis ATCC 6633, Enterococcus faecium JCM 5804 and Staphylococcus aureus TLU as described by Method 2 (Figure 1). Among these 7 strains, DC1.8, NC3.19 and NC3.5 strains had highest inhibition to 3 indicator strains. These three strains were chosen to test sensitive capability with proteases. 


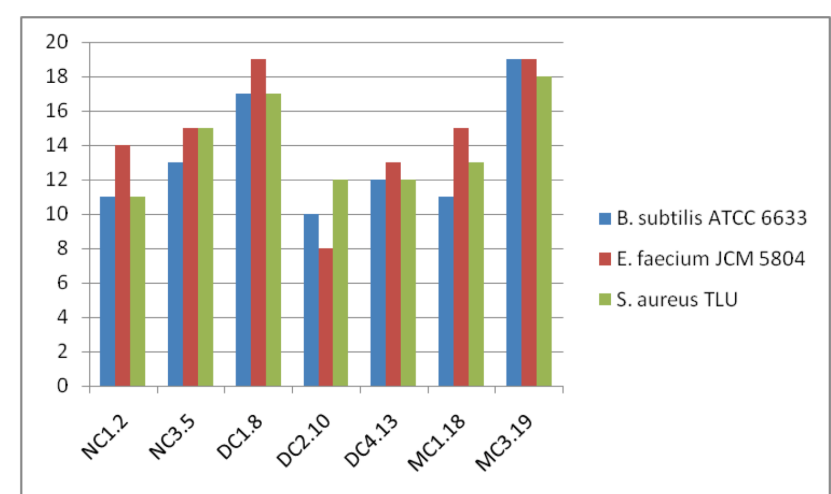

Figure 1. Ability of inhibiton to B. subtilis ATCC 6633, E. faecium JCM 5804 and $S$. aureus TLU

\subsection{Sensitive capability with proteases}

The antibacterial activity of the lactic acid bacteria can be based on disposable compounds, such as reuterin, reutericyclin, acid 2-Pyrrolidone-5-carboxylic. During of their growth, some other antibacterial compounds are produced as lactic acid, $\mathrm{H}_{2} \mathrm{O}_{2}$, bacteriocin, etc. (Ouwehand and Satu Vesterlund, 2004). According to Ladzinski et al (2000), bacteriocins are synthesized in ribosome and rapidly resolved by proteases in the human digestive system. Thus, sensitive capability with protease of these antibacterial compounds of the NC3.5, DC1.8 and MC3.19 were checked for seeking strains producing bacteriocin.

Table 2 showed that antibacterial activity of DC1.8 and MC3.19 strains was reduced comparing to positive control (C) when protease $\mathrm{K}(\mathrm{K})$, papain $(\mathrm{P}), \alpha$ - chymotrypsin $(\alpha)$ and trypsin $(\mathrm{T})$ were added to the supernatant of MRS media after culturing (example in Figure 2). While NC3.5 strain had antibacterial activity similar to positive control.

It indicated that antibacterial compounds produced by DC1.8 and MC3.19 strains were bacteriocins.
Table 2. Sensitive capability with protease of NC3.5, DC1.8 and MC3.19 strains

Protease Inhibition to L. plantarum JCM1149

\begin{tabular}{lccc} 
& \multicolumn{3}{c}{$(\mathrm{D}-\mathrm{d} \pm 2 \mathrm{~mm})$} \\
\cline { 2 - 4 } & $\mathrm{NC3.5}$ & $\mathrm{DC} 1.8$ & $\mathrm{MC} 3.19$ \\
\hline Protease K & 15 & 3 & 4 \\
Papain & 13 & 5 & 5 \\
$\alpha$ - chymotrypsin & 14 & 2 & 0 \\
Trypsin & 14 & 4 & 4 \\
Positive Control & 15 & 18 & 19
\end{tabular}

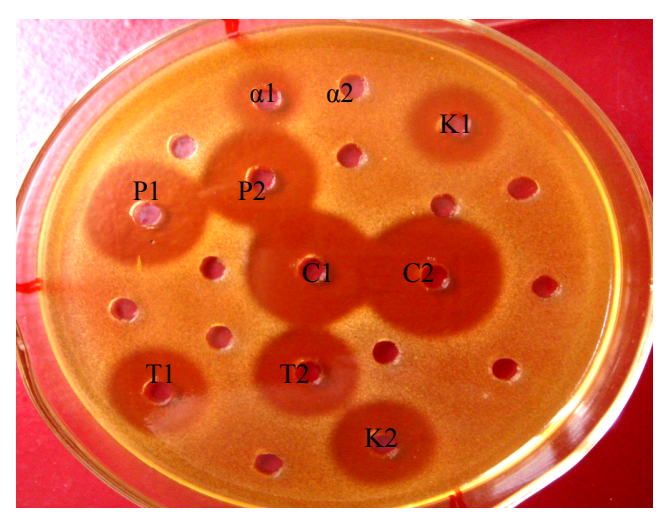

Figure 2. Sensitive capability with protease of DC1.8

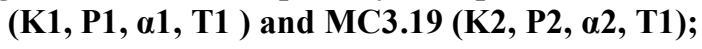
C1, C2: positive control

\subsection{Fermentation of sugars of DC1.8 and MC3.19 strains}

Biochemical properties were confirmed by fermentation efficacy of sugars based on standard API 50 CHL Kit (Table 3). Comparison with the database of APILAB Plus version 4.0 software revealed $97.9 \%$ homology of DC1.8 with Lactobacillus acidophilus, and 99.9\% homology of MC3.19 with Lactococcus lactis.

Table 3. The fermentation efficacy of sugars of DC1.8 and MC3.19 strains based on standard API 50 CHL Kit

\begin{tabular}{|c|c|c|c|c|c|}
\hline Substance & DC1.8 & MC3.19 & Substance & DC1.8 & MC3.19 \\
\hline Control & - & - & Esculine & + & + \\
\hline Glycerol & - & - & Salicine & + & + \\
\hline Erythritol & - & - & Cellobiose & + & + \\
\hline D-Arabinose & - & - & Maltose & + & + \\
\hline L- Arabinose & - & + & Lactose & + & + \\
\hline Ribose & - & + & Melibiose & - & + \\
\hline D-Xylose & - & + & Saccharose & + & + \\
\hline L-Xylose & - & - & Trehalose & + & + \\
\hline Adonitol & - & - & Inuline & - & - \\
\hline$\beta$-Methyl-xyloside & - & - & Melezitose & - & - \\
\hline Galactose & + & + & D-Raffinose & + & $\mathrm{W}$ \\
\hline D-Glucose & + & + & Amidon & + & + \\
\hline D-Fructose & + & + & Glycogene & - & - \\
\hline D-Mannose & + & + & Xylitol & - & - \\
\hline L-Sorbose & - & - & $\beta$-Gentiobiose & + & + \\
\hline Rhamnose & - & - & D-Turanose & - & - \\
\hline Dulcitol & - & - & D-Lyxose & - & - \\
\hline Inositol & - & - & D-Tagatose & + & $\mathrm{W}$ \\
\hline Mannitol & $\mathrm{W}$ & + & D-Fucose & - & - \\
\hline Sorbitol & - & - & L-Fucose & - & - \\
\hline a-Methyl-D-mannoside & - & - & D-Arabitol & - & - \\
\hline a-Methyl-D-glucoside & - & + & L-Arabitol & - & - \\
\hline N-Acetyl glucosamine & + & + & Gluconate & - & + \\
\hline
\end{tabular}




\begin{tabular}{lccccc}
\multicolumn{1}{c}{ Substance } & DC1.8 & MC3.19 & Substance & DC1.8 & MC3.19 \\
\hline Amygdaline & + & + & 2-ceto-gluconate & - & - \\
Arbutine & + & + & 5-ceto-gluconate & - & - \\
\hline
\end{tabular}

-: negative; +: positive; w: weak

\subsection{Analysis of 16s rRNA gene of DC1.8 and MC3.19 strains}

PCR products of 16S rRNA gene of DC1.8 and MC3.19 were approximately $1500 \mathrm{bp}$. Sequences of $16 \mathrm{~S}$ rRNA gene were analyed and compared to some homologous sequences in GENBANK. MEGA3 sofware was used for assessment phylogeny relationship of survey sequences (Figure 3 ).

The phylogeny relationship between groups of organism are often presented in the form of phylogenetic tree. The ends of the branches show exists of organism groups, the branching points of the tree denotes our ancestors, and length of branches indicates evolution time or differentiation of DNA sequences (Nei M. and Kumar S., 2000).
Figure 3 specified DC1.8 strain closely related to Lactobacillus acidophilus JCM2121. MC3.19 strain closely related to Lactococcus lactis NIRD712 and Lactococcus lactis JCM7638.

Furthermore, bootstrap values in branched position were very high, and bootstrap values $>70 \%$ would be equivalent to $95 \%$ reliability (Hillis D.M. and Bull J.J., 1993). That proved the reliability in phylogeny analysis result.

The result of classification by genetic analysis of $16 \mathrm{~s}$ rRNA gene was same to result of chemical characteristics. That also coincided with shape characteristic, that's supposed genus Lactobacillus is rod-shape and genus Lactococcus is coccus-shape (Salminen S. et al., 2004).

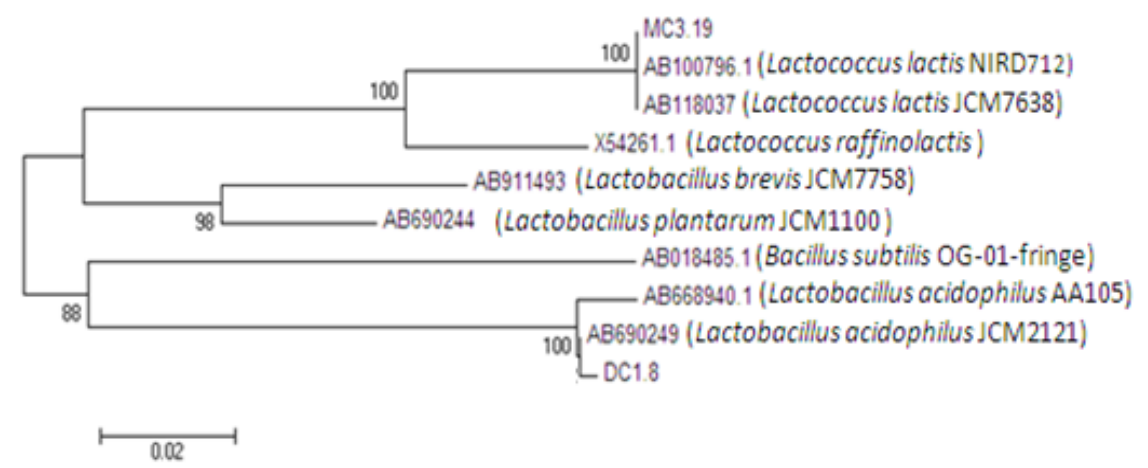

Figure 3. Neighbour-joining phylogenetic tree based on 16S rRNA gene sequences. Numbers at the root of the branch are the bootstrap value.

\section{Conclusion}

From 15 samples (consist of 5 samples of Vietnamese fermented pork roll; 5 samples of salted field cabbage and 5 samples of fresh cow milks) 22 strains of lactic acid bacteria were isolated. Of 22 isolates, 3 strains were selected from 3 different sample sources because of high inhibition to Lactobacillus plantarum JCM1149, Bacillus subtilis ATCC 6633, Enterococcus faecium JCM 5804 and Staphylococcus aureus TLU. However, only 2 strains (DC1.8 isolated from salted field cabbage and MC3.19 isolated from fresh cow milk) were sensitive with proteases. That means antibacterial compounds of them are bacteriocin.

These strains were classified base on physicochemical properties and genetic relationship of 16s rRNA gene. The results showed that DC1.8 strain belong to Lactobacillus acidophilus, MC3.19 strain belongs to Lactococcus lactis.

Acknowledgement: This work has been supported by VNU University of Engineering and Technology under project "Selection of lactic acid bacteria producing compounds inhibiting foodborne-poisoning bacteria" (CN16.02).

\section{References}

[1] De Vuyst L., Vandamme E.J. (1994) Antimicrobial potential of lactic acid bacteria. In: Bacteriocins of Lactic Acid Bacteria (De Vuyst L., Vandamme E.J. Eds.), pp. 91-142. Blackie Academic and Professional, London.

[2] De Vuyst L., Vandamme E.J. (1994) Bacteriocins of Lactic Acid Bacteria: Microbiology, Genetics and Applications. Blackie Academic and Professional, London.

[3] Gilliland S.E. (1986) Bacterial Starter Cultures for Foods. CRC, Boca Raton, FL.

[4] Hillis D.M., Bull J.J. (1993), “An empirical test of boostrapping as a method for assessing confidence in phylogenetic analysis", Systematic Biology, 42, pp. 182-192.

[5] Lazdunski C.J, Geli V (2000) Bacteriocins. Encyclopaedia of Molecular Biology 3: 1909-1914.

[6] Nei M. and Kumar S. (2000), Molecular evolution and phylogenetic, Oxfort University Press.

[7] Ouwehand, Arthur and Satu Vesterlund (2004). Antimicrobial Components from Acid lactic Bacteria. Acid lactic bacteria. University of Turku, Finland, 
375-397.

[8] Salminen S, Von Wright A, Ouwehand A (2004) Lactic Acid Bacteria. Marcel Dekker Inc.

[9] Schillinger U, Lucke FK. (1989). Antibacterial Activity of Lactobacillus sake Isolated from Meat. Applied and Environmental Microbiology 55: 1901-1906.
[10] Stiles M.E.,1996. Biopreservation by lactic acid bacteria. Antonie van Leeuwenhoek Int. J. Gen. Mol. Microbiol. 70, 331-345.

[11] Teuber M, (2003) The genera of Lactic Acid Bacteria.6.3: 173 - 200 . 